\title{
THREATENED MISCARRIAGE AND PREGNANCY LOSS: CONTEMPORARY ASPECTS OF THE PROBLEM
}

DOI: 10.36740/WLek202005134

\author{
Oksana M. Nepyivoda, Tetiana B. Ryvak \\ DEPARTMENT OF CLINICAL PHARMACY, PHARMACOTHERAPY AND MEDICAL STANDARDIZATION, DANYLO HALYTSKY LVIV NATIONAL MEDICAL UNIVERSITY, \\ LVIV, UKRAINE
}

\begin{abstract}
The aim is to examine the state of a miscarriage of pregnancy problem and approaches to its solution based on current Ukrainian and international experience; to investigate a relevant set of terms and their interpretations that are tangible to the above-mentioned problem.

Materials and methods: modern information sources available for miscarriage and pregnancy loss. System analysis, bibliographic, bibliosemantic, comparative-and-analytical methods were used.

Conclusions: A relevant set of terms and their interpretations tangential to the identified problem $(n=13)$ have been researched. It was found that the achievement of rational pharmacotherapy in patients with the threat of miscarriage is complicated mainly by the presence of 4 factors: extragenital pathology, burdened obstetric-gynecological anamnesis, lack of adequate drugs and possibilities of their prescription, especially in the $1^{\text {st }}$ half of pregnancy. Disregarding these factors when prescribing medicines increases the risk of drug-related problems occurrence, prolongation of hospitalization and the adverse outcome of treatment (miscarriage). The results of the analysis of available information flow have shown the existence of terminological ambiguity related to the threat of miscarriage, in particular, there are often the following terms: spontaneous abortion, threatened abortion etc. instead of miscarriage, the threatened miscarriage which are recommended by international experts both in native Ukrainian and foreign researches. Unintended use of inadequate terms, in particular, «pregnancy failure» may form negative influence on women, cause the exaggeration of their condition, induce the feeling of despair, guilt, uncertainty associated with loss of the pregnancy.
\end{abstract}

KEY WORDS: miscarriage of pregnancy, threatened miscarriage, pharmacotherapy, terms and their interpretation

Wiad Lek. 2020;73(5):1021-1027

\section{INTRODUCTION}

According to WHO statistics, the frequency of premature termination of pregnancy varies $10-25 \%$ in different countries [1-3]. The results of the demographic indicators analysis for the last 15-20 years have been shown that Ukraine is in deep demographic crisis. The problem of a miscarriage of pregnancy (MP) is especially significant: direct reproductive losses related to it result in 36-40 thousand of unborn babies in Ukraine annually. These data claim that the research in this area is one of the most important tasks of modern Ukrainian medicine [4].

According to experts' evaluation, early pregnancy losses occur in $10 \%$ of all clinically recognized pregnancy, approximately $80 \%$ happens in $1^{\text {st }}$ trimester $[1,3,5,6]$. At the same time, about $5 \%$ of women suffer from 2 abortions in a row [7]. Taking into account the high frequency of early pregnancy losses, which reaches $25 \%$ of the total number of pregnancy in the present conditions with the lack of tendency to decrease it and its negative influence on women's reproductive health, the issue of rational monitoring of early stages of pregnancy in order to prevent reproductive losses is extremely important [3, 8-11]. Thus, in the early stages of pregnancy, the foundations of placental insufficiency and delayed fetal development are laid, defects of pregravid preparation are realized, prophylactic opportunities which could contribute to the reduction of prenatal and maternal mortality are lost. The main reserve for the reduction of early reproductive losses is the establishment of an adequate monitoring level and an effective system for the prevention and treatment of threatened abortion (miscarriages) $[3,8,11-13]$. The threat of miscarriage in the early stages of pregnancy is one of the most important problems of modern health care both in Ukraine and in the world $[1,3,5,8,10,11,13-17]$. As already mentioned above the problem of MP is especially significant, it is one of the most important components of modern health care of many countries. However, the relevance, purpose and design of our work are determined by the need of review and unified interpretation of terms relevant to the issue of MP, often controversy positions and views on the marked problem, the lack of systematic research in this perspective in Ukraine.

\section{THE AIM}

The purpose of the article is to examine the state of MP problem and approaches to its solution based on current Ukrainian and international experience; to investigate a relevant set of terms and their interpretations that are tangible to the above-mentioned problem. 


\section{MATERIALS AND METHODS}

Objects: the process of providing medical assistance regarding the problem; modern evidence-based information; information array of clinical trials and meta-analysis results [14-16, 18-24]; a relevant set of terms and concepts related to MP. The research methods: system analysis, bibliographic, bibliosemantic, comparative and analytical.

\section{REVIEW AND DISCUSSION}

The first stage of our research involved the implementation of the search and analysis of the conceptual and terminological apparatus in relation to the problem of MP [14, $15,25-27]$. It is established that considerable discussions among the foreign scientists cause terminological aspects, tangential to the problem of MP. Thus, the unintentional use of inadequate terms, such as «pregnancy failure», can form negative influence on women, cause the exaggeration of their condition, induce the feeling of despair, guilt, uncertainty associated with loss of pregnancy $[14,21]$, and besides, depression can be developed. There are also other terminological ambiguities associated with the termination of pregnancy, in particular, there are often the following terms: spontaneous abortion, threatened abortion etc. in- stead of miscarriage, the threat of miscarriage (threatened miscarriage) recommended by international experts both in domestic and foreign researches (Table 1). It should be noted that in Ukraine, both at the legislative level and in clinical practice, the same outdated terminology is still being used: threatening abortion, spontaneous abortion, habitual abortion, etc. $[3,25,26]$. Analysis results of the available information flows pertaining to the problem have been shown the necessity to revise and standardize the terminology relating to the outlined problem, in particular, to find the possibility of adapting and integrating international experience on the above issues in Ukrainian realities. Considering all the above mentioned, we present our glossary of interpretations $(n=13)$ pertaining to the problem under investigation in the context of the revised (preliminary) and recommended by authoritative international experts terms as a result of our bibliosemantic research (Table I).

Miscarriage of pregnancy is spontaneous termination of pregnancy from the conception to 37 weeks. MP from the conception to 22 weeks is called spontaneous miscarriage. Spontaneous termination of pregnancy from 22 to 37 weeks is called preterm labor. Miscarriage of pregnancy is one of the major problems of practical obstetrics. Currently,

Table I. Glossary of terms $(n=13)$ related to the problem under investigation, created by us as a result of a bibliosemantic analysis (own researches using relevant scientific sources $[14,15])$

\begin{tabular}{|c|c|c|}
\hline Recommended term & Revised term & Definition \\
\hline Miscarriage & Spontaneous abortion & $\begin{array}{l}\text { Loss of pregnancy for up to } 20 \text { full weeks or less than } 400 \text { grams } \\
\text { of fetal weight. }\end{array}$ \\
\hline Threatened miscarriage & Threatened abortion & Any vaginal bleeding revealed up to 20 weeks of gestation. \\
\hline Inevitable miscarriage & Inevitable abortion & Miscarriage is inevitable or miscarriage in the course. \\
\hline Incomplete miscarriage & Incomplete abortion & $\begin{array}{l}\text { Miscarriage when the fetus or placenta cannot be naturally } \\
\text { removed from the mother. }\end{array}$ \\
\hline Complete miscarriage & Complete abortion & $\begin{array}{l}\text { Miscarriage that does not require medical or surgical } \\
\text { intervention. }\end{array}$ \\
\hline Missed miscarriage & Missed abortion & $\begin{array}{l}\text { Ultrasound confirmed non-viability of pregnancy without } \\
\text { bleeding. }\end{array}$ \\
\hline $\begin{array}{l}\text { Anembryonic pregnancy / Blighted } \\
\text { ovum }\end{array}$ & $\begin{array}{l}\text { Early fetal demise / } \\
\text { Delayed miscarriage / } \\
\text { Silent miscarriage }\end{array}$ & $\begin{array}{l}\text { A blighted ovum occurs when a fertilized egg implants in the } \\
\text { uterus but doesn't develop into an embryo. It is also referred } \\
\text { to as an anembryonic (no embryo) pregnancy and is a leading } \\
\text { cause of early pregnancy failure or miscarriage. }\end{array}$ \\
\hline Miscarriage with infection (sepsis) & Septic abortion & Miscarriage is complicated by infection of the pelvic organs. \\
\hline Recurrent miscarriage & Recurrent abortion & 3 or more consecutive miscarriages of the same woman. \\
\hline Pregnancy of unknown location & - & $\begin{array}{l}\text { No signs of either intra- or extrauterine pregnancy or retained } \\
\text { products of conception in a woman with a positive pregnancy } \\
\text { test. }\end{array}$ \\
\hline Pregnancy of 'uncertain viability' & - & $\begin{array}{l}\text { Intrauterine sac ( }<20 \mathrm{~mm} \text { mean diameter) with) no obvious yolk } \\
\text { sac or fetus or Fetal echo }<6 \mathrm{~mm} \text { crown-rump length with no } \\
\text { obvious fetal heart activity. In order to confirm or refute viability, } \\
\text { a repeat scan at a minimal interval of } 1 \text { week is necessary. }\end{array}$ \\
\hline Heterotopic pregnancy & - & $\begin{array}{l}\text { Intra- + extrauterine pregnancy (e.g., in the fallopian tubes, } \\
\text { cervix, ovaries, abdominal cavity). }\end{array}$ \\
\hline Gestational trophoblastic disease & - & $\begin{array}{l}\text { Is a term used for a group of pregnancy-related tumours. These } \\
\text { tumours are rare, and they appear when cells in the womb start } \\
\text { to proliferate uncontrollably. Also known as a molar pregnancy. }\end{array}$ \\
\hline
\end{tabular}


Table II. The main causes and factors of MP (adapted for Slava V Gaufberg, 2017 [30])

\begin{tabular}{|c|c|}
\hline $\begin{array}{l}\text { Causes of miscarriage of the } \\
1 \text { st and } 2 \text { nd trimester: }\end{array}$ & $\begin{array}{l}\text { - Embryonic anomalies make up of } 80-90 \% \text { of spontaneous miscarriages in the } 1 \text { st trimester. } \\
\text { - Chromosomal abnormalities are the most common cause of spontaneous miscarriage. More } \\
\text { than } 90 \% \text { of cytogenetic and morphological errors are eliminated by spontaneous miscarriage. } \\
\text { - Chromosomal abnormalities were found in more than } 75 \% \text { of the fetuses with the threat of } \\
\text { miscarriage in the first trimester. } \\
\text { - The rate of chromosomal abnormalities increases with age in women over } 35 \text { years. }\end{array}$ \\
\hline $\begin{array}{l}\text { Acute maternal health } \\
\text { factors include the } \\
\text { following: }\end{array}$ & $\begin{array}{l}\text { - Infections (such as rubella, cytomegalovirus, ureaplasma, listeria, mycoplasma infection and } \\
\text { toxoplasmosis). } \\
\text { - Injuries. } \\
\text { - A severe emotional shock can also cause miscarriage in the 1st and 2nd trimesters. }\end{array}$ \\
\hline $\begin{array}{l}\text { Other factors that may cause } \\
\text { miscarriage: }\end{array}$ & - Alcohol, tobacco, cocaine and other drugs. \\
\hline Endocrine factors: & $\begin{array}{l}\text { - Potentially contribute to MP } 10-20 \% \text { of cases. } \\
\text { - Luteal phase deficiency (i.e., dysfunction of the corpus luteum with insufficient progesterone } \\
\text { production) which is the most common endocrine abnormalities and lead to the threat of } \\
\text { miscarriage. } \\
\text { - Hypothyroidism. } \\
\text { - Polycystic ovary disease. }\end{array}$ \\
\hline Infectious factors: & $\begin{array}{l}\text { - Bacterial, viral, parasitic, fungal and zoonotic infections associated with the recurrence of } \\
\text { spontaneous miscarriage. }\end{array}$ \\
\hline Immunological factors: & $\begin{array}{l}\text { - Developing embryo and trophoblast can be considered immunologically foreign to the } \\
\text { maternal immune system. } \\
\text { - Immunological factors may contribute up to } 60 \% \text { recurrence of spontaneous miscarriages. }\end{array}$ \\
\hline Various factors: & $\begin{array}{l}\text { - Environmental factors, medicines, placental disorders, iatrogenic and causes from the father's side. } \\
\text { - Various factors can be up to 3\% of recurrent spontaneous miscarriages. }\end{array}$ \\
\hline $\begin{array}{l}\text { Age and demographic } \\
\text { factors: }\end{array}$ & $\begin{array}{l}\text { - Age affects the risk of threatened miscarriage in women. } \\
\text { - In women, younger than } 20 \text { years miscarriage occurs in } 12 \% \text { of pregnancy. } \\
\text { - In women over } 20 \text { years old miscarriage occurs in } 26 \% \text { of pregnancy. }\end{array}$ \\
\hline
\end{tabular}

MP frequency ranges from 10 to $25 \%$; in the $1^{\text {st }}$ trimester it can reach $50 \%$, in the $2^{\text {nd }}$ trimester $-20 \%$, in the $3^{\text {rd }}$ trimester - $30 \%[3,9,13,16,28]$. We have identified the following risk factors for threatened miscarriage $(n=4)$ (own research based on available information flow $[3,13$, 15, 29]): 1) socio-biological factors: low socioeconomic status (low income, low level of education, malnutrition), job-related to physical activity, stress; 2) data obstetric and gynecological history: maternal age - under 16 and over 30 years, preterm birth anamnesis, burdened obstetrical anamnesis; 3 ) presence of extragenital pathology: diabetes mellitus, arterial hypertension and other diseases of the cardiovascular system, bronchial asthma, pyelonephritis, usual intoxication (alcohol use, smoking), drug addiction; 4) complications of pregnancy: multiple fertility, breech presentation of the fetus (prematurity in 20\% of cases), placenta previa (premature delivery is 5 times more often), placental detachment (premature delivery is 4 times more often), infection, intrauterine infection, gestosis (preeclampsia). The threat of termination of pregnancy is the increase in contractile activity of the uterus, which can potentially lead to detachment of the fetal egg and its removal from the uterus. Habitual MP is spontaneous termination of pregnancy 2 or more consecutive times. In early terms (2-4 weeks) spontaneous miscarriages by more than $50 \%$ of cases are due to chromosomal abnormalities [5, 6, 22]. Therefore, it is not recommended to use hormonal and immune therapies when the cause of the miscarriage is not clarified and woman's examination was not conducted before pregnancy. At the threat of termination in the $1^{\text {st }}$ trimester, ultrasound should be performed urgently to determine the viability of the embryo, because signs of a threat often appear after its death. During early pregnancy, vaginal bleeding and the presence of abdominal/pelvic pain of any degree are the threat of miscarriage. Approximately $1 / 4$ of all pregnant women have a certain degree of vaginal bleeding during the first two trimesters. About $1 / 2$ of these cases progress to actual miscarriage. Bleeding and pain that accompanies threatened miscarriage are usually not too intense $[13,29]$.

Given the high incidence of early pregnancy loss, as well as a large number of the above-mentioned risk factors for the threatened miscarriage and their negative impact on women's reproductive health, we have analyzed the main causes and factors of MP (Table II).

The prediction of a successful pregnancy depends on the etiology of previous spontaneous miscarriages, age of the patient, and the manifestation of pregnancy on ultrasound. According to statistics, in women under 35, the risk of threatened miscarriage is about $10 \%$, while at the age of 40 and over, it reaches $45 \%$ [6]. In women with recurrent MP correction of endocrine pathology has a better prognosis for successful pregnancy (>90\%). In women with unknown cause of previous loss of the pregnancy, the 
probability of achieving successful pregnancies is $40-80 \%$. When transvaginal ultrasound of the pelvic organs shows an embryo, at least 8 weeks according to gestational age and cardiac activity, the miscarriage in patients under 35 years is $5 \%$ and over 35 years - $8 \%$. The overall level of threat of miscarriage in patients over 35 years is $14 \%$, and under 35 years $-7 \%$ [31].

Epidemiological surveillance data suggest that spontaneous miscarriages and induced abortions account for about $4 \%$ of deaths related to pregnancy in the USA [20]. The formation of complications of pregnancy occurs in the early stages of its development during the invasion of the trophoblast. A normal healthy placenta is formed due to a successful invasion providing protection during pregnancy. In the case when the trophoblast cells do not penetrate the wall of the spiral arteries, the vessels remain narrow, the blood circulation is disturbed and the defective placenta is formed, placental insufficiency develops. This, in turn, leads to complications of pregnancy, such as growth retardation of the fetus, MP with termination on various terms and pre-eclampsia, etc. There are still no effective methods and clear algorithms for the treatment of the listed complications in the world. In particular, premature births are still the urgent problem of practical medicine [32]. The direction which has been actively developing for the last years and is used for pharmacotherapy (PhT) of premature delivery - tocolytic therapy, has shown its failure. It turned out that the administration of tocolytics (fenoterol, hexoprenaline) appeared not to reduce the frequency of premature delivery. The usage of such medicines can only delay the onset of delivery for 2-7 days but does not provide indices reduction of premature delivery and improvement of neonatal sequences. Further maintenance of therapy is inappropriate due to the absence of clinical efficacy from the tocolytic PhT within 3 days. Preventive usage of any tocolytics also does not prevent the onset of premature delivery $[29,33]$.

Thus, the main focus of modern obstetrics is the prevention of complications of pregnancy. To do this, first of all, it is necessary to identify women at risk of the complicated course of pregnancy, and secondly, their pregravid preparation and prevention of complications during pregnancy. However, complicated pregnancy is a multifactorial process, the task of the physician is to identify the risk factors before pregnancy and compensate them by all available methods. After compensation, you can start preparation; otherwise, it will lead to a complicated course of pregnancy and its loss. The forecast is increasingly unfavorable with each subsequent loss $[1,5,13]$.

Treatment of the threat of miscarriage in the vast majority is performed in a hospital, in some clinical situations - in outpatient departments. Medicinal therapy is prescribed by a doctor, depending on: 1) causative factor inducing the risk of miscarriage; 2) term of pregnancy and 3) the individual features of the pregnant woman taking into account the data of the complex examination. The earlier the PhT of the threat of miscarriage begins, the higher percentage of maintenance of pregnancy is. The treatment of the threat of miscarriage is complex and involves the following measures: 1) complete bed rest; using psychotherapy sessions; 2) the administration of sedative drugs (tincture of valerian, motherwort);3) usage of spasmolytic drugs (papaverine, drotaverine, magnesium sulfate); the administration of vitamins (E, C); 4) hormones are usually used in the $1^{\text {st }}$ trimester ensuring the normal course of pregnancy (these drugs include progesterone); 5) if there is hyperandrogenemia and/or immune factors of the threat of termination of pregnancy in the $1^{\text {st }}$ trimester, corticosteroids are prescribed (dexamethasone, methylprednisolone); 6) if cervical insufficiency is revealed, conservative or surgical therapy is performed. Surgical treatment can be done by mechanical contraction of the inferior internal orifice of the uterus or by the method of stitching of its outer orifice; 7) in the case of blood discharge hemostatic drugs (tranexamic acid) can be used; 8) if it is necessary, $\mathrm{PhT}$ of the revealed infections is carried out $[8,34,35]$.

However, during pregnancy hormones should be administered strictly according to the doctor's prescription and after the previous examination. Rules for the administration of hormonal medicines during pregnancy: 1) the administration of hormonal medicines should be strictly proved; 2) it is important the continuous monitoring efficacy of hormonal PhT 3) hormonal medicines should be administered in minimal doses; 4) estrogens are prescribed from the 5th week of pregnancy, and gestagens - after 8 and up to 14-16 weeks; in the future the formed placenta will begin to perform the function of the formation of hormones $[3,25,36]$.

The treatment of women with the threat of termination of pregnancy does not necessarily involve hospitalization. A woman on a bed rest moves less, takes more food, all these causes induce a disturbance of sleep, muscular atrophy, cardiovascular and gastrointestinal disorders, weight gain, stress, depression, etc. Each of these components is an independent factor of complicated course of pregnancy. Increasing the risk of thrombosis is an adverse reaction and dangerous consequence of hospitalization and bed rest. The results of the Danish cohort clinical trial, during which out of 1.3 million pregnant women $1 / 2$ were hospitalized for various causes, have shown that hospitalization and stay in hospital only for 3-7 days 12.2 times increases the risk of thrombophlebitis complications from 3.5 to 42.1 per 100 thousand women [23].

In today's conditions, the pathogenetic validity of the use of progestogens for the purpose of PhT of a threatened miscarriage is beyond doubt. Since absolute or relative progesterone deficiency is one of the main components of the pathogenesis of early reproductive losses, the progesterone administration is considered to be entirely appropriate regardless of the genesis of MP [24]. At the same time, the fact that, in a number of cases, hormonal pharmacotherapy does not give proper effect is attracting attention and alarming; it stimulates the search for new approaches to correction of hormonal disorders. Thus, the development of the differentiated treatment schemes of threatened miscarriage as a predictor of early reproduc- 
tive losses, taking into account pathogenetic aspects, is an extremely urgent task.

Dydrogesterone is one of the drugs of choice at risk of miscarriage $[28,34,36]$. Indication of its administration is the lack of progesterone in the woman body, confirmed by the laboratory method. Dydrogesterone is a synthetic analog of progesterone and structurally quite similar to the natural woman progesterone. When using dydrogesterone orally is indicated its selective effect on specific uterine receptors that are sensitive to it. Positive effects of dydrogesterone: does not affect blood clotting; does not disturb liver function; does not cause the development of virilization (hirsutism), both in women and in the embryo, which is a characteristic feature of some other progestogens. PhT schemes and dosage of dydrogesterone are assorted by the physician in each case individually according to the recommendations of the instructions for medical use. Dosage of dydrogesterone in case of the threat of miscarriage is 40 mg once and then it is $10 \mathrm{mg}$ every 8 hours until symptoms disappear completely. If there isn't any positive dynamics, you can increase the dosage by $10 \mathrm{mg}$ every 8 hours. After eliminating the symptoms of threatened miscarriage, $\mathrm{PhT}$ with the optimally chosen dose is continued for 7 days, then the dosage is gradually reduced. If, after a dose reduction, the symptoms of threatened miscarriage are restoring, you should return to the previous dosage at which they disappeared. Dydrogesterone is usually prescribed in the first trimester of pregnancy - up to 16 weeks until the placenta is formed, which will then take on the function of producing hormones $[34,36]$.

The meta-analysis of studies, where 2158 women were involved, have shown that progesterone PhT significantly reduces the incidence of spontaneous miscarriages in women with recurrent miscarriage compared with placebo (relative risk $0.39\{\mathrm{RR}\}$; $95 \%$ confidence interval $\{\mathrm{CI}\}$ 0.21-0.72) and do not increase side effects towards mother and fetus $[18,37]$. In pregnant, medication of choice is micronized progesterone because the physiological effects are completely equivalent to endogenous progesterone and its metabolites. Micronized progesterone is prescribed to pregnant women only vaginally, which provides the effect of primary passage through the cervix and allows it to reach its maximum concentration in the uterus. The administration of progesterone is also necessary for women with the threat of termination of pregnancy with burdened gynecological history. Bases for the further course of pregnancy are laid out in the $1^{\text {st }}$ trimester, and the threat of termination greatly worsens the further forecast in this period.

The results of a number of clinical trials have shown that in 9 out of 10 pregnant women with burdened obstetric-gynecological anamnesis, the threat of miscarriage remained at late stages of pregnancy. Practically all of them had an infusion tocolytic pharmacotherapy of $\beta$-mimetics, followed by prolonged administration in tablet form. Histological signs of placental insufficiency were detected later in all pregnant women. In each of the $3^{\text {rd }}$ cases, placental insufficiency was combined with delayed fetal development. The inclusion of progesterone in the complex of $\mathrm{PhT}$ of the threatened miscarriage has led to significant improvement in the further course of pregnancy. Threatened miscarriage rate (the frequency of the threat of $\mathrm{P}$ termination) in the second half of pregnancy decreased by 1.5 times and the necessity of $\beta$-mimetics administration reduced by 2 times when progesterone was used to 12-16 weeks of pregnancy. In women who took progesterone for a prolonged period, the threatened miscarriage rate was 2.6 times lower and the necessity of $\beta$-mimetics administration reduced 11 times $[18,33,34,37]$.

The traditional administration of different multivitamin complexes does not improve obstetric and prenatal outcomes, at the same time, it increases the risk of multiple pregnancies by $38 \%$ [12]. First of all, this is due to excessive vitamin A and folic acid (when its dose is more than 400 mcg per day). Protein and energy supplements are not indicated for the treatment of pregnant women, as they lead to weight gain and increase the threat of termination of pregnancy [38]. Only the balanced diet provides a favorable course and outcome of pregnancy [39].

In 2007, Russian experts published clear guidelines for pregnancy, where 3 key positions were highlighted: the $1^{\text {st }}$ mandatory prenatal screening to detect fetal chromosomal abnormalities; the $2^{\text {nd }}$ position is devoted to the use of folic acid; the $3^{\text {rd }}$ - prevention of preterm birth. This document noted that all women who are going to become pregnant should be taking $400 \mathrm{mcg}$ per day of folic acid for at least 30 days before pregnancy onset and continuing throughout the $1^{\text {st }}$ trimester. Additional taking of folic acid not only reduces the risk of developing of neural tube defects in the fetus but also other adverse complications: congenital heart disease, maxillofacial defects, low birth weight, preterm birth and autism [35].

In addition to the role of the universal regulator of many biochemical processes in the body as a whole during pregnancy, the importance of magnesium as a specific factor necessary for the proper functioning of the placenta and the system of «mother-placenta-fetus» increases. The placenta is formed and actively functions starting from the earliest terms of pregnancy up to the very birth of a child. Among the tissues of the human body, the placenta is characterized by one of the highest levels of magnesium content. Placental magnesium-dependent proteins control [33]: metabolism in the placenta; the condition of the muscular, immune, connective tissue systems; proliferation and apoptosis. Magnesium deficiency naturally leads to a decrease in its total amount in the placenta in complexes with both adenosine triphosphate and proteins. Reducing the activity of magnesium-dependent placental proteins leads to inadequate functioning of the placenta. A successful pregnancy is found to depend on adequate implantation and placentation with the establishment of the complete blood flow in the "mother-placenta-fetus» system to a large extent. Therefore, the deficiency of magnesium can disrupt the normal placental process and lead to the threat of termination of pregnancy in the first trimester or to further development of fetoplacental insufficiency. Thus, a sufficient supply of the woman body with magnesium in 
the period of pregnancy is absolutely necessary to maintain the biological functions of the placenta and the system of «mother-placenta-fetus» in general $[29,33,39]$.

The positive effect of medicines of magnesium on the pregnancy course is due to such pharmacological effects as a reduction in the tone of the uterus, vasodilation and corresponding improvement of the blood flow in the vessels of the placenta, decreased platelet aggregation, the regulation of vascular tone, etc. [39]. These medicines are traditionally used in obstetric and gynecological practice in complex PhT of threatened and recurrent miscarriage, which is undoubtedly one of the most urgent problems of modern obstetrics and gynecology. Clinical symptoms of the threat of termination of pregnancy correlate with a decrease in magnesium concentration in blood serum [19]. Parenteral or tablet drug forms of magnesium compounds are used depending on the presence and severity of clinical symptoms as well as the purpose (therapeutic or prophylactic). Moreover, the preventive magnesium administration in patients with MP in history is not less important than their use for therapeutic purpose. The effectiveness of oral administration of organic salts of magnesium up to the $25^{\text {th }}$ week of pregnancy for the purpose of prevention was demonstrated in a meta-analysis of 7 clinical trials with 2,689 patients performed by experts of the Cochrane community. In particular, the risk of the threat of termination was reduced by $62 \%$ (RR: 0.38 ; 95\% CI: 0.16-0.90) [18].

\section{CONCLUSIONS}

1. The results of bibliosemantic research on the basis of available information flow with the indicated problem claim that there is the existence of terminological ambiguity related to the threat of miscarriage. In particular, there are often the following terms both in native Ukrainian and foreign sources: spontaneous abortion, threatened abortion, etc. instead of miscarriage, the threat of miscarriage (threatened miscarriage) recommended by international experts. In this regard, there is a need to revise and standardize the terminology $(n=13)$ relating to the outlined problem, in particular, to find the possibility of adapting and integrating international experience on the above issues in Ukrainian realities. Unintended use of inadequate terms, in particular, "pregnancy failure» may form negative influence on women, cause the exaggeration of their condition, induce the feeling of despair, guilt, uncertainty associated with loss of the pregnancy, moreover, depression can be developed, which acquires a special social significance.

2. According to the results of our analysis of modern domestic and foreign experience regarding the studied problem, it has been established that the achievement of the rationality of $\mathrm{PhT}$ in pregnant women with the risk of miscarriage is complicated by the presence of extragenital pathology, burdened obstetric-gynecological anamnesis, lack of adequate drugs and possibilities of their prescription, especially in the first half of pregnancy. Failure of taking into account these factors in the prescription of medicines increases the risk of occurrence of drug-related problems, prolongation of hospitalization and the adverse outcome of treatment (miscarriage). The management of MP and threatened miscarriage in the $1^{\text {st }}$ trimester of pregnancy should be based on the current international clinical guidelines for safe and effective use of medicines. It should provide a comprehensive evidence-based approach to treatment, taking into account a number of warnings and factors related, in particular, to the complex psycho-emotional state of women in this period.

\section{REFERENCES}

1. Ectopic pregnancy and miscarriage: diagnosis and initial management. National Institute for Health and Care Excellence. Clinical Guidelines. April 2019; 126. Available from: https://www.nice.org.uk/guidance/ng126

2. Pregnancy Loss (Before 20Weeks) Research Information. US Department of Health and Human Services. Last Reviewed 2017. Available from: https://www.nichd.nih.gov/health/topics/pregnancyloss/researchinfo

3. Vovk IB, Horovenko NH, Trokhimovich OV etal. Ranni reproduktyvni vtraty: etiolohiya, patohenetychni aspekty, diahnostychni ta likuval'ni zakhody [Early reproductive loss: etiology, pathogenetic aspects, diagnostic and therapeutic measures]. Health of Ukraine 2016; 1:37-40. (UA)

4. Khomyak N.V., Mamchur V.I., Khomyak Ye.V. Kliniko-farmakologicheskiye osobennosti sovremennykh lekarstvennykh form mikronizirovannogo progesterona, primenyayushchikhsya vo vremya beremennosti [Clinical and pharmacological features of modernmedicinal forms of micronized progesterone, used in pregnancy]. Medical aspects of women's health 2015;2(88):28-35. (Ru)

5. Early pregnancy loss. Practice Bulletin No. 150. The American College of Obstetricians and Gynecologists 2015. Available from: https://www. acog.org/-/media/Practice-Bulletins/Committee-on-Practice-BulletinsGynecology/Public/pb150.pdf

6. The Johns Hopkins Manual of Gynecology and Obstetrics (4 ed.). Lippincott Williams \& Wilkins. 2012; 438-439.

7. Garrido-Gimenez C., Alijotas-Reig J. Recurrent miscarriage: causes, evaluation and management. Postgraduate Medical Journal. 2015:91(1073):151-162.

8. Vovk I.B., Horovenko N.H., Trokhimovich O.V. et al. Dyferentsiyovanyy pidkhid do likuvannya zahrozlyvoho vykydnya rannikh terminiv hestatsiyi [Differentiated approach to the treatment of threatened miscarriage early gestation]. Health of Woman. 2015; 1(97):108-112.

9. ZhukS.I., Kalinka Ya.N.,Sidelnikova V.M. Nevynashivaniye beremennosti: novyy vzglyad na staruyu problemu [Miscarriage: a new look at the old problem]. Medical aspects of women's health 2007; 5(1). Available from: https://mazg.com.ua/ua-issue-article-49\#Nevynashivanieberemennosti-novyy-vzglyad-na-staruyu-problemu (Ru)

10. Makarchuk 0.M., Yatsyshyn N.H. Optymizatsiya hormonal'noyi pidtrymky v razi nevynoshuvannya vahitnosti v ranni terminy hestatsiyi [Optimization of hormonal support in case of miscarriage in the early gestational period]. Health of Woman. 2009; 3:87-89. (UA)

11. Posiseeva L.V. Ranniye reproduktivnyye poteri: problemy i resheniya [Early reproductive losses: problems and solutions]. Gynecology. 2012; 6:38-41. (Ru)

12. Makarov 0.V., Borovkina E.I., Sheshukova N.A. et al. Rol'ugrozy preryvaniya beremennosti v geneze razvitiya fetoplatsentarnoy nedostatochnosti [The role of the threat of termination of pregnancy in the genesis of development of fetoplacental insufficiency]. Gynecology. 2010;5:33-38. (Ru)

13. Nazarenko L.H. Aktual'ni uyavlennya shchodo problemy nevynoshuvannya vahitnosti [Actual views on the problem of miscarriage]. Health of Woman. 2013; 1:36-42. Available at: http://z-l. com.ua/upload/pdf/522.pdf (UA) 
14. Queensland Clinical Guideline: Early pregnancy loss. Maternity and Neonatal Clinical Guideline 2011;39. Available at: https://www.health. qld.gov.au/qcg/documents/g-epl.pdf

15. The management of early pregnancy loss. Royal College of Obstetricians and Gynecologists, Guideline. 2006; 25:33. Available from: http://www. jsog.org/GuideLines/The_management_of_early_pregnancy_loss.pdf

16. Nakhai-Pour H.R., Broy P., Sheehy 0. et al. Use of nonaspirin nonsteroidal anti-inflammatory drugs during pregnancy and the risk of spontaneous abortion. Canadian Medical Association Journal.2011; 183(15) 1713-1720.

17. Nepyivoda 0., Ryvak T. Evaluation of rationality of pharmacotherapy in case of threatened miscarriage and development of a model of pharmaceutical care as an information-and-explanatory support. Pharmacia. 2018; 65(1):41-51.

18. Threatened miscarriage. Cochrane Database of Systematic Reviews. Cochrane Central Register of Controlled Trials. Issue 5-12. May 2019. Available from: https://www.cochranelibrary.com/search

19. Medscape. Drugs \& Diseases. Pregnancy \& Lactation. Magnesium sulfate 2018. Available from: http://reference.medscape.com/drug/ mgs04-magnesium-sulfate-344444\#6

20. Berghella V. Obstetric Evidence Based Guidelines. Second edition. Tutorial 2012; 304.

21. Robinson GE. «Pregnancy loss». Best practice \& research. Clinical obstetrics \&gynaecology 2014; 28(1):169-178.

22. Vaiman D. Genetic regulation of recurrent spontaneous abortion in humans. Biomedical Journal 2015; 38(1):11-24.

23. Virkus R.A., Løkkegaard E., Lidegaard 0. et al. Risk factors for venous thromboembolism in 1.3 million pregnancies: a nationwide prospective cohort. PLoS One 2014;9(5):e96495. Available at: http://www.ncbi.nlm. nih.gov/pubmed/24788753

24. Wahabi H.A., Fayed A.A., Esmaeil S.A. et al. Progestogen for treating threatened miscarriage. Cochrane Database of Systematic Reviews. 2018; 8: CD005943 Available from:https://www.cochranelibrary.com/ cdsr/doi/10.1002/14651858.CD005943.pub5/epdf/full

25. Vytyah iz klinichnoho protokolu z akushers'koyi dopomohy «Nevynoshuvannya vahitnosti». Nakaz MOZ Ukrayiny [Excerpt from the clinical protocol for obstetric care «Miscarriage of Pregnancy». Ministry of Health of Ukraine order No. 624 from November 3, 2008]. Available from: http://www.moz.gov.ua/ua/portal/ dn_20081103_624.html (UA)

26. Baza standartiv medychnoyi dopomohy v Ukrayini [Ukrainian Medical Care Standards Database from September 28, 2017]. Available from: http://www.dec.gov.ua/mtd/index.html (UA)

27. Moscrop A. 'Miscarriage or abortion?' Understanding the medical language of pregnancy loss in Britain; a historical perspective. Medical Humanities 2013: 39(2):98-104.

28. Sidelnikova VM. Nevynashivaniye beremennosti-sovremennyy vzglyad na problem [Miscarriage - a modern view of the problem. Obstetrics and Gynecology]. 2007; 5:24-27. (Ru)

29. Mozheiko L.F. Nevynashivaniye beremennosti:Uchebno-metodicheskoye posobiye [Miscarriage: Tutorial]: Minsk: Belarusian State Medical University. 2013; 28. (Ru)

30. Slava V. Gaufberg. Early Pregnancy Loss in Emergency Medicine. Updated 2018. Available from: https://emedicine.staging.medscape. com/article/795085-overview

31. Laurino M.Y., Bennett R.L., Saraiya D.S. et al. Genetic evaluation and counseling of couples with recurrent miscarriage: recommendations of the National Society of Genetic Counselors. Journal of Genetics and Genomics. 2005; 14(3):165-181.
32. Rittenberg V., Sobaleva S., Ahmad A. et al. Influence of BMI on risk of miscarriage after single blastocyst transfer. Human Reproduction. 2011; 26(10):2642-2650.

33. Zaporozhan V.M. Akusherstvo ta hinekolohiya [Obstetrics and gynecology]. Second edition, corrected. Tutorial: K. 2017; 1032. (UA)

34. Pisareva S.P. Differentiated approach to the use of medicines of gestagenic actions in case of miscarriage. Health of Woman. 2012; 1(67):123-126.

35. Tetruashvili N.K., Sidelnikova V.M. Sovremennyye printsipy terapii krovotecheniy v pervom i vo vtorom trimestrakh beremennosti [Modern principles of treatment of bleeding in the first and second trimesters of pregnancy]. Journal of Obstetrics and Female Diseases. 2007; 2:84-90. (Ru)

36. Vovk I.B., Kondratiuk V.K., Trohimovich 0.V. et al. Zahroza pereryvannya vahitnosti v ranni terminy: suchasni pohlyady na etiolohiyu, patohenez, diahnostyku ta likuvannya (ohlyad literatury) [The threat of miscarriage in the earlystages, contemporaryviews on the etiology, pathogenesis, diagnosis and treatment (literature review)]. Health ofWoman. 2012; 5(71):50-56. (UA)

37. Sidelnikova V.M. Gormonal'nyye aspekty nevynashivaniya beremennosti [Hormonal aspects miscarriage of pregnancy]. Medical aspects of woman's health. 2007; 4(7):19-22. (Ru)

38. Sidelnikova V.M. Endokrinologiya beremennosti v norme i pri patologii [Endocrinology of pregnancy under the normal and pathological conditions]. Textbook: M.: MEDpress inform. 2009; 352. (Ru)

39. Dadak K. Defitsit magniya v akusherstve i ginekologii [Deficiency of magnesium in obstetrics and gynecology]. Obstetrics, gynecology and reproduction. 2013; 7(2):6-14. (Ru)

The work was carried out in accordance with the plan of scientific works of the Department of Clinical Pharmacy, Pharmacotherapy and Medical Standardization, Danylo Halytsky Lviv National Medical University «System of improvement medical care quality for population of Ukraine with implementation clinical pharmacist professional activity».

\section{ORCID and contributionship:}

Oksana M. Nepyivoda - 0000-0002-2858-9238 A,C,E

Tetiana B. Ryvak - 0000-0002-9491-1109 B,D,F $^{\text {B }}$

\section{Conflict of interest:}

The Authors declare no conflict of interest

\section{CORRESPONDING AUTHOR Tetiana B. Ryvak \\ Department of Clinical Pharmacy, \\ Pharmacotherapy and Medical Standardization, Danylo Halytsky Lviv National Medical University, 69 Pekarska str., 79010, Lviv, Ukraine \\ tel: +380322944748 \\ e-mail: tanusha1905@gmail.com}

Received: 26.01 .2020

Accepted: 30.03 .2020

A - Work concept and design, B - Data collection and analysis, C - Responsibility for statistical analysis, D-Writing the article, $\mathbf{E}$-Critical review, $\mathbf{F}-$ Final approval of the article 